\title{
A Functional Link for Major TCR Expansions in Healthy Adults Caused by Persistent Epstein-Barr Virus Infection
}

\author{
Sharon L. Silins, Simone M. Cross, Kenia G. Krauer, Denis J. Moss, Christopher W. Schmidt, and Ihor S. Misko \\ Epstein-Barr Virus Unit, Queensland Institute of Medical Research and University of Queensland Joint Oncology Program, Brisbane, \\ Queensland, Australia 4029
}

\begin{abstract}
Dramatic clonal expansions of unknown functional significance have been documented in the $T$ cell receptor (TCR) $\alpha \beta$ peripheral blood repertoires of apparently healthy adults. In this study, we provide evidence that persistent infection with the ubiquitous Epstein-Barr virus (EBV) causes major distortions within the memory repertoire of healthy virus carriers. Using complementarity determining region 3 (CDR3) length analysis to measure repertoire diversity, dominant expansions that dramatically skewed the entire TCRBV6 blood repertoire towards oligoclonality were enriched in the $\mathrm{CD}^{+} \mathrm{CD}^{2} 5 \mathrm{RO}^{+} \mathrm{CD} 45 \mathrm{RA}^{-}$subset of $\mathrm{HLA} \mathrm{B8}{ }^{+}$ healthy virus carriers. Evidence of phenotypic heterogeneity between individuals was also observed for these expansions based on their variable coexpression of CD45RO and CD45RA. TCR junctional region sequencing revealed that these expansions were clonal and that they represented commonly selected HLA B8-restricted memory cytotoxic T cells that recognize the immunodominant latent EBV epitope, FLRGRAYGL. Furthermore, the functional identity of these virus-specific $\mathrm{CD}^{+} \mathrm{T}$ cells was confirmed by their FLRGRAYGL-specific cytotoxicity. Therefore, the functional significance of dramatic clonal expansions in healthy adults can be linked in some cases to virus-specific $\mathrm{CD}^{+} \mathrm{T}$ cells that play an essential role in immunosurveillance. This first identified link for expansions in the circulation of healthy adults strongly implies that restricted-memory TCR responses to environmental antigens play a pivotal role in expansion development, which should have an important impact on studies interpreting TCR expansion patterns in health and disease. (J. Clin. Invest. 1998. 102:15511558.) Key words: CDR3 • T cell memory • CD8 • CD45RO • antigen-specific $\mathrm{T}$ cells
\end{abstract}

\section{Introduction}

Unusually high expansions of $\alpha \beta$ T cells within the human peripheral repertoire are known to occur in various blood-associated malignancies, autoimmune, inflammatory, and infectious

Address correspondence to Dr. Sharon L. Silins, Queensland Institute of Medical Research, The Bancroft Centre, 300 Herston Rd., Brisbane, Queensland, Australia 4029. Phone: 61-7-3362-0342; FAX: 61-7-3362-0106; E-mail: sharonS@qimr.edu.au

Received for publication 8 June 1998 and accepted in revised form 21 August 1998.

J. Clin. Invest.

(C) The American Society for Clinical Investigation, Inc. 0021-9738/98/10/1551/08 \$2.00

Volume 102, Number 8, October 1998, 1551-1558

http://www.jci.org diseases (1-7). Clonality and conserved features of antigen specificity in many of these expansions have been linked to the pathogenesis of the disease. More recently, however, the significance of clonal dominance in disease has been questioned given that dramatic clonal expansions have also been reported, although at a lower frequency than in disease, within the circulating T cell repertoires of apparently healthy individuals (8-16). In healthy individuals, $\alpha \beta \mathrm{T}$ cell expansions can persist unaltered for years, predominantly occur within the $\mathrm{CD} 8^{+} \mathrm{T}$ lymphocyte subset $(8,10,14,15)$, often express a $\mathrm{CD}_{45 \mathrm{RO}^{+} \text {mem- }}$ ory phenotype $(9,11,12)$, and appear to accumulate with age $(8,9)$. A key issue is what causes these major repertoire perturbations and what functional significance they have in cellmediated immunity and in disease development. In particular, do expansions in the circulation arise as a normal consequence of repeated exposure of the immune system to environmental antigens and to persistent virus infections? Alternatively, are they autoreactive $\mathrm{T}$ cells, similar to $\mathrm{B}$ cells in benign monoclonal gammopathies, that are thought to be responding to premalignant conditions and age-related defects?

Diversity within the $\mathrm{T}$ cell repertoire can be measured by studying the distribution of $\mathrm{T}$ cell receptor $(\mathrm{TCR})^{1}$ rearrangements. The majority of T cells express an $\alpha \beta$ TCR heterodimer that is generated through somatic recombination of variable (TCRAV and TCRBV), diversity (TCRBD), and joining (TCRAJ and TCRBJ) gene elements during T cell ontogeny (for review see reference 17). Repertoire diversity is further increased by the imprecise joining of the different gene segments and the quasi-random insertion or deletion of nucleotides at the V-(D)-J junctional regions that span the major antigen binding site or complementarity determining region 3 (CDR3) (18-20). Therefore, the CDR3 loop is highly variable in length and in codon usage between functionally distinct TCR clonotypes. Extreme clonotypic expansions do not necessarily elevate the frequencies of TCRBV gene families, as they have been detected within populations with normal TCRBV gene frequencies $(9,12)$.

Several features of the $\mathrm{CD}^{+} \mathrm{T}$ cell memory response to EBV make it an ideal model system to address a possible link between persistent virus infection and the presence of large clonal expansions within the peripheral blood repertoires of healthy individuals. Firstly, we have shown previously that the class I-restricted memory response to the latent EBV epitope, FLRGRAYGL, is restricted by a single TCRBV6S2/BJ2S7 clonotype that is highly conserved in many HLA B8 ${ }^{+}$individuals (21). (TCRBV6S2 replaces BV6S3*a under the new designation according to Arden et al. [22].) Secondly, functional assays have estimated that this public clonotype is highly fre-

1. Abbreviations used in this paper: CDR, complementarity determining region; CTL, cytotoxic T cell; IM, infectious mononucleosis; TCR, $\mathrm{T}$ cell receptor. 
quent within the peripheral blood repertoire (23) and that memory EBV-specific cytotoxic T cell (CTL) responses are stably maintained for life (24). The present study has explored the impact that selection of this EBV-specific clonotype has on the TCR $\alpha \beta$ repertoire of healthy virus carriers. By examining the diversity of the TCRBV6 repertoire within different $T$ cell populations of HLA $\mathrm{B}^{+}$adults, we herein show that expansion of the EBV-specific clonotype in healthy virus-infected individuals dramatically skews the entire $\mathrm{CD}^{+} \mathrm{CD}^{+} \mathrm{RO}^{+}$ $\mathrm{CD}_{45 \mathrm{RA}^{-}}$memory BV6 repertoire towards oligoclonality. This study identifies a basis for environmental antigens in the development of extreme $\mathrm{T}$ cell expansions in the blood of healthy adults.

\section{Methods}

Donors. Peripheral blood samples were taken from two healthy, HLA B8 ${ }^{+}$, long-term EBV-seropositive donors (viral capsid antigen $\mathrm{IgG}^{+}, \mathrm{EBV}$ nuclear antigen $\mathrm{IgG}^{+}$), D1 and D2, aged 51 and $37 \mathrm{yr}$, respectively. Peripheral blood was also taken from two HLA $\mathrm{B}^{+}$, EBV-seronegative donors (viral capsid antigen $\mathrm{IgG}^{-}$, EBV nuclear antigen $\mathrm{IgG}^{-}$), D3 and $\mathrm{D} 4$, aged 56 and $55 \mathrm{yr}$, respectively. PBMCs were isolated from heparinized blood by centrifugation over FicollPaque (Pharmacia Biotechnology, Melbourne, Australia). The HLA $\mathrm{B}^{+}$status of each donor was initially determined by FACScan ${ }^{\circledR}$ analysis of PBMCs using anti-HLA B8 mAb (clone 59HA-1; One Lambda, Los Angeles, CA) and confirmed by serological typing of the donor's PBMCs.

Isolation and enrichment of human $C D 8^{+} C D 45 R A^{+} C D 45 R O^{-}$, $C D 8^{+} C D 45 R O^{+} C D 45 R A^{-}$, and $C D 8^{+} C D 45 R O^{+} C D 45 R A^{+} T$ cells. $1-2 \times 10^{7}$ PBMCs were incubated with anti-human CD4 mAblabeled magnetic beads (Dyna beads M-450; DYNAL, Melbourne, Australia) to enrich for $\mathrm{CD}^{+}$lymphocytes according to the manufacturer's recommendation. The $\mathrm{CD}^{+}$-enriched population was centrifuged and the pelleted cells were stained for three-color, immunofluorescent flow cytometry using anti-human CD8 mAb conjugated with tricolor (clone 3B5; CALTAG, Sydney, Australia), anti-human CD45RA mAb conjugated with FITC (clone L48; Becton Dickinson, Sydney, Australia), and anti-human CD45RO mAb labeled with PE (clone UCHL-1; Becton Dickinson). Cells were sorted into three subsets, a $\mathrm{CD}^{+} \mathrm{CD}^{2} 5 \mathrm{RA}^{+} \mathrm{CD} 45 \mathrm{RO}^{-}, \mathrm{CD}^{+} \mathrm{CD}^{2} 5 \mathrm{RO}^{+} \mathrm{CD} 45 \mathrm{RA}^{-}$, and $\mathrm{CD}^{+} \mathrm{CD}^{+} 5 \mathrm{RO}^{+} \mathrm{CD} 45 \mathrm{RA}^{+}$population, using a Becton Dickinson FACS $^{\circledR}$ Vantage Flow Cytometer. The purity of the recovered cells was $>98 \%$.

RNA isolation and $c D N A$ synthesis. Total RNA was extracted from $1-5 \times 10^{5} \mathrm{PBMCs}$ or sorted $\mathrm{CD}^{+} \mathrm{CD}^{-} 45 \mathrm{RA}^{+} \mathrm{CD}^{4} 5 \mathrm{RO}^{-}$,

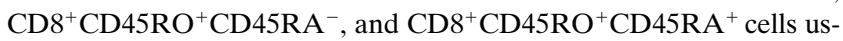
ing Total RNA Isolation Reagent (Advanced Biotechnologies, London, UK). First strand cDNA was synthesized using an antisense TCRBC primer $\left(\mathrm{C}_{\mathrm{b} 1}\right)$ as described previously (21). For all RNA and cDNA reactions, a negative control was included where either cells or RNA were replaced with water.

TCRBV6 PCR amplification. TCRBV6 transcripts were amplified to saturation with a $5^{\prime}$ TCRBV6 family-specific primer (V $\left.\beta 6\right)$ (25) and a nested 3' TCRBC-specific primer $\left(\mathrm{C}_{\mathrm{b} 2}\right)$ (21). Amplifications were performed in $25-\mu l$ reaction volumes using first strand cDNA representing material from $1-5 \times 10^{4}$ cells, 10 pmol of each $5^{\prime}$ and $3^{\prime}$ primer, $200 \mu \mathrm{M}$ dNTPs, $1.5 \mathrm{mM} \mathrm{MgCl}_{2}, 1.25 \mathrm{U}$ of $T a q$ polymerase (AmpliTaq Gold; Perkin-Elmer Corp., Norwalk, CT), and a GeneAmp PCR 9600 system (Perkin-Elmer Corp.). The PCR conditions consisted of denaturation at $95^{\circ} \mathrm{C}$ for $15 \mathrm{~s}$, annealing at $55^{\circ} \mathrm{C}$ for $40 \mathrm{~s}$, and extension at $72^{\circ} \mathrm{C}$ for $40 \mathrm{~s}$ for 35 cycles, followed by a 5 -min final extension at $72^{\circ} \mathrm{C}$. PCR products were separated on $2 \%(0.5 \times$ Tris-buffered EDTA) NuSieve GTG agarose gels (FMC BioProducts, Rockland, ME), excised, and purified using a QIAEX gel extraction kit (Qiagen, Chatsworth, CA).
Repertoire diversity analysis: CDR3 length determination and quantitation of CDR3 distribution. The technique of CDR3 length determination and quantitation of CDR3 distribution to analyze TCR repertoire diversity is based on the methodology described by Pannetier et al. (26). QIAEX-purified TCRBV6 PCR products were labeled with a nested $3^{\prime}$-FAM fluorophore-labeled primer specific for the TCRBC gene (CßP*: 5'-FAM-TTCTGATGGCTCAAACAC-3'; Research Genetics Inc., Huntsville, AL) in a PCR run-off reaction. PCR conditions were identical to those described above, except that $2 \%$ of QIAEX-purified TCRBV6 PCR product was used as a template for five cycles of elongation (run-off) and a 5-min final extension at $72^{\circ} \mathrm{C}$. The fluorescent PCR run-off products were heat-denatured at $95^{\circ} \mathrm{C}$ for $2 \mathrm{~min}$ and were separated on a $6 \%$ acrylamide gel together with size standards (GENESCAN-1000 ROX; Applied Biosystems, Brisbane, Australia) on an Applied Biosystems 373A DNA sequencer. Data were processed using the GENESCAN Analysis 2.1 Software (Applied Biosystems) which records the fluorescence intensity in each peak. Percent relative peak intensity is the specific peak area/total area of all peaks.

Repertoire diversity analysis: TCR $V-D-J$ junctional region sequencing. QIAEX-purified TCRBV6 PCR products were ligated into the pGEM-T Vector System (Promega, Madison, WI) and then used to transform Epicurian coli SURE Competent Cells (Stratagene, La Jolla, CA) according to the respective manufacturers' instructions. Plasmid inserts were amplified by PCR and QIAEXextracted according to the conditions described above, and then sequenced in both directions using the $\mathrm{V} \beta 6$ and $\mathrm{C}_{\mathrm{b} 2}$ primers with a PRISM Ready Reaction DyeDeoxy Terminator Cycle Sequencing Kit and an ABI377 DNA sequencer (Applied Biosystems). Diversity within the BV6 gene family was measured by the frequency at which a particular cloned TCR V-D-J insert occurred. $n$ signifies the number of identical TCR V-D-J junctional region sequences/total number of recombinant clones tested.

Cytotoxicity assay. Unsorted PBMCs and sorted populations of $\mathrm{CD}^{+} \mathrm{CD}^{4} 5 \mathrm{RA}^{+} \mathrm{CD}_{45 \mathrm{RO}^{-}}$and $\mathrm{CD}^{+} \mathrm{CD}^{-} 45 \mathrm{RO}^{+} \mathrm{CD} 45 \mathrm{RA}^{-}$cells from seropositive donor $\mathrm{D} 2$ were activated weekly by stimulation with the $\gamma$-irradiated ( $80 \mathrm{~Gy}$ ) LCL from an HLA A1/B8 homozygous individual, BM, at a stimulator/responder cell ratio of 1:200. After $32 \mathrm{~d}$, these populations were used as effectors against HLA A1/B8 homozygous PHA $\mathrm{T}$ cell blasts, with and without adsorbed FLRGRAYGL peptide $(100 \mu \mathrm{g} / \mathrm{ml}, 0.5 \mathrm{ml})$. Peptides were purchased from Chiron Mimotopes (Melbourne, Australia), dissolved in DMSO, and diluted in serum-free RPMI 1640 medium for use in cytotoxicity assays. Target cells were incubated with $100 \mu \mathrm{Ci}$ of ${ }^{51} \mathrm{Cr}$ at $37^{\circ} \mathrm{C}$ for $90 \mathrm{~min}$, with and without peptide, washed twice by centrifugation, and used in standard $4-\mathrm{h}{ }^{51} \mathrm{Cr}$-release assays. The mean spontaneous lysis for targets in culture medium was $<20 \%$, the mean maximum lysis in $0.5 \%$ SDS was $>90 \%$ of total uptake, and the variation about the mean specific lysis was $<5 \%$.

\section{Results}

$E B V$-infected healthy adults have dramatically distorted TCRBV6 memory repertoires. Previously we have shown that the class I-restricted memory response to the latent EBV epitope, FLRGRAYGL, is dominated in many HLA $\mathrm{B}^{+}$individuals by a single TCRBV6S2/BJ2S7 clonotype (21). To determine whether clonal expansions of this public EBV-specific clonotype can be linked to repertoire distortions within healthy individuals, we examined the extent of diversity within the peripheral TCRBV6 repertoire of two normal adult EBV-seropositive, HLA B8 ${ }^{+}$donors, D1 and D2. Both donors have been found previously to have a highly restricted FLRGRAYGL-specific TCR memory response (21), with circulating CTL precursor frequencies of the EBV clonotype as high as 1:2,000 PBMCs reported for donor D1 (23). Repertoire diversity was mea- 


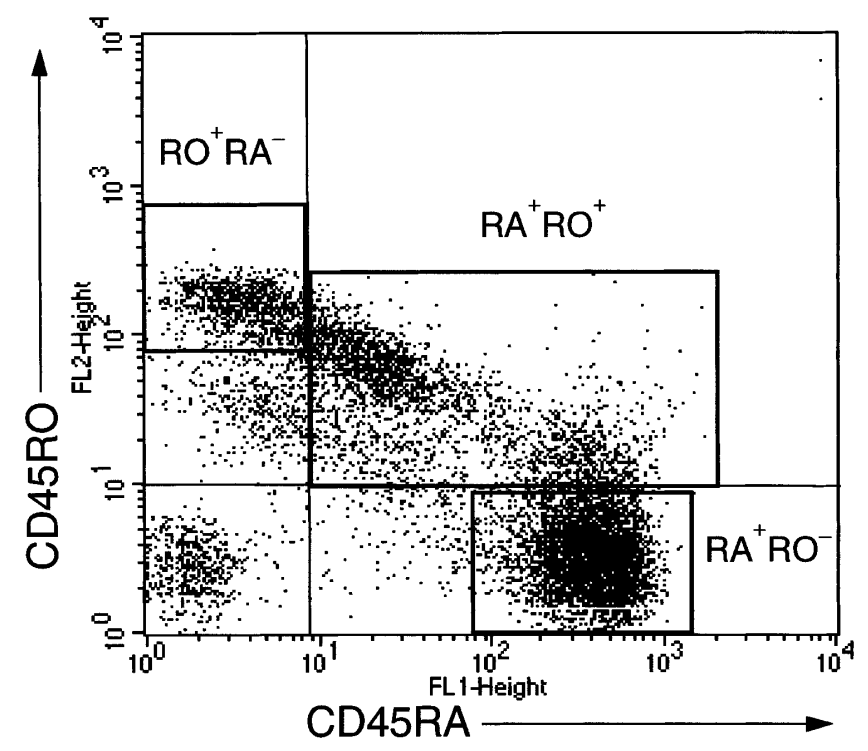

Figure 1. Three-color immunofluorescence analysis of PBMCs of adult donor D2. $\mathrm{CD} 8^{+}$-enriched cells were simultaneously stained with tricolor-conjugated CD8 in combination with FITC-conjugated CD45RA and PE-conjugated CD45RO mAbs. Cells were gated on size and tricolor fluorescence. Three distinct populations could be defined within $\mathrm{CD}^{+} \mathrm{T}$ cells from adult PBMCs: $\mathrm{CD} 45 \mathrm{RO}^{+} \mathrm{CD}^{+} 5 \mathrm{RA}^{-}$ $\left(\mathrm{RO}^{+} \mathrm{RA}^{-}\right), \mathrm{CD} 45 \mathrm{RO}^{+} \mathrm{CD}_{45} \mathrm{RA}^{+}\left(\mathrm{RO}^{+} \mathrm{RA}^{+}\right)$, and $\mathrm{CD} 45 \mathrm{RA}^{+}$ $\mathrm{CD}^{2} 5 \mathrm{RO}^{-}\left(\mathrm{RA}^{+} \mathrm{RO}^{-}\right)$cells.

sured by a PCR-based approach that determines the distribution of CDR3 lengths within a given TCRBV family; gaussianshaped peak profiles represent a diverse array of clonotypes of varying CDR3 lengths, whereas oligoclonal peak profiles have been shown to represent clonally expanded $\mathrm{T}$ cells (for review see reference 27). TCRBV6 family repertoire diversity was analyzed ex vivo in unsorted PBMCs and in sorted populations of either $\mathrm{CD}^{+} \mathrm{CD}^{+} 5 \mathrm{RA}^{+} \mathrm{CD}^{4} \mathrm{RO}^{-}$(naive) or $\mathrm{CD}^{+} \mathrm{CD}^{-} 45 \mathrm{RO}^{+}$ $\mathrm{CD} 45 \mathrm{RA}^{-}$(memory) $\mathrm{T}$ cells that were $>98 \%$ pure. Fig. 1 shows the three-color immunofluorescence FACS $^{\circledR}$ profile from individual D2. Consistent with the demarcation parameters of previous studies in defining memory and naive $\mathrm{T}$ cell populations, only the strongly staining single-positive $\mathrm{CD} 45 \mathrm{RO}^{+}$ $\mathrm{CD}_{45 \mathrm{RA}^{-}}$cells and CD45RA ${ }^{+} \mathrm{CD} 45 \mathrm{RO}^{-}$cells were collected, respectively. CDR3 length profiles obtained from three independent analyses of these different $\mathrm{T}$ cell populations were found to be highly reproducible (Fig. 2). An extreme predominance of a rearrangement with an 8-amino acid CDR3 length, corresponding exactly in size to the TCRB chain $\mathrm{CDR} 3$ region of the public EBV-specific clonotype, was recorded in the $\mathrm{CD}^{+} \mathrm{CD}^{4} 5 \mathrm{RO}^{+} \mathrm{CD} 45 \mathrm{RA}^{-} \mathrm{T}$ cell subset of each EBV-seropositive donor (Fig. $2 \mathrm{~A}$ ); relative peak intensities were 80 and $71 \%$ for donors D1 and D2, respectively (Fig. $2 B$ ). This dramatic expansion was enriched within the $\mathrm{CD}_{45 \mathrm{RO}^{+} \text {mem- }}$ ory subset since gaussian-like profiles of polyclonality were recorded in both unsorted PBMCs and in sorted $\mathrm{CD}^{+}$

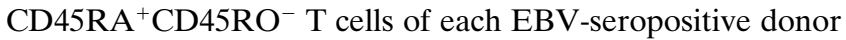
(Fig. $2 \mathrm{~A}$ ). The apparent clonal predominance of an 8-amino acid CDR3 rearrangement was found to be specific to EBVinfected donors, since TCRBV6 repertoire analysis of two HLA B8 ${ }^{+}$, EBV-seronegative adults (D3 and D4) showed no evidence of repertoire focusing (Fig. 2, $A$ and $B$ ).
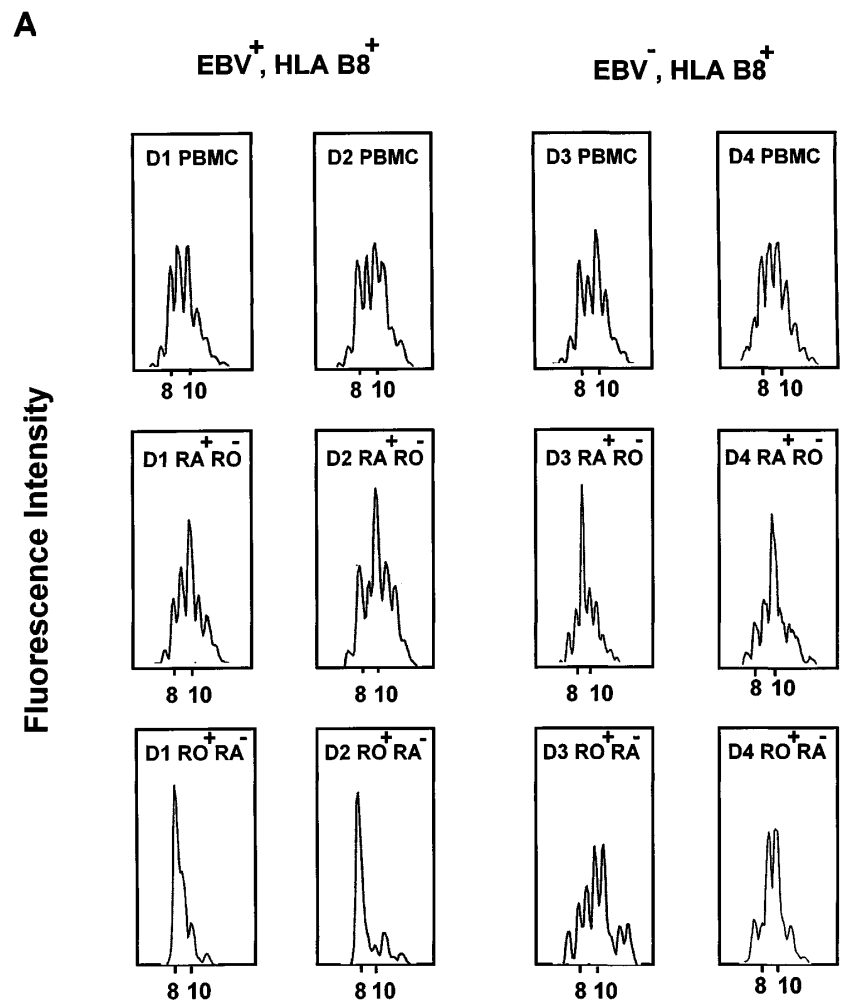

\section{CDR3 Length}

B

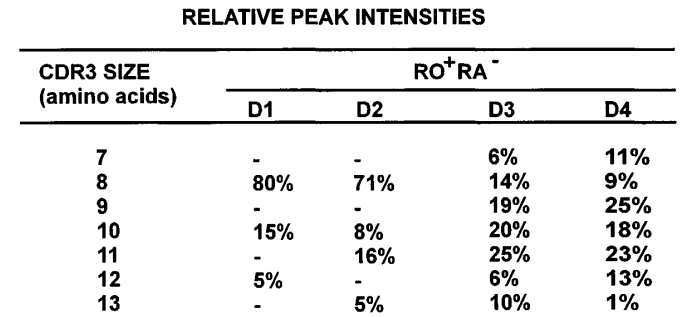

Figure 2. CDR3 length distribution in TCRBV6 within different T cell populations of HLA B8 ${ }^{+}$, EBV-seropositive (D1, D2), and EBVseronegative (D3, D4) adults. ( $A$ ) Profiles are displayed of fluorescence intensity (arbitrary units) as a function of CDR3 size (amino acids) for TCRBV6 of unsorted PBMCs and sorted populations of $\mathrm{CD}^{+}{ }^{+} \mathrm{CD} 45 \mathrm{RA}^{+} \mathrm{CD} 45 \mathrm{RO}^{-}\left(\mathrm{RA}^{+} \mathrm{RO}^{-}\right)$and $\mathrm{CD} 8^{+} \mathrm{CD} 45 \mathrm{RO}^{+}$

$\mathrm{CD}^{2} \mathrm{RA}^{-}\left(\mathrm{RO}^{+} \mathrm{RA}^{-}\right)$cells. CDR3 length, defined by Chothia et al. (43), is deduced from the fragment size. Each CDR3 peak is spaced three nucleotides or one amino acid apart. $(B)$ Relative percent peak intensities derived from the $\mathrm{CDR} 3$ length profiles of the $\mathrm{CD} 8^{+}$

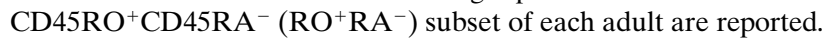
Relative peak intensities are calculated as described in Methods.

EBV-specific TCR clonotypes account for the TCRBV6 expansions in the blood. Repertoire diversity was next examined at the clonotype level by determining the TCR V-D-J junctional region sequences of recombinant clones that contained TCRBV6 inserts from the different $\mathrm{T}$ cell populations (Fig. 3, $A-C$ ). In the $\mathrm{CD}^{+} \mathrm{CD} 45 \mathrm{RO}^{+} \mathrm{CD} 45 \mathrm{RA}^{-}$subset of both seropositive donors, a striking percentage of the total TCRBV6 repertoire was found to be dominated by a BV6S2/ $\mathrm{BJ} 2 \mathrm{~S} 7$ rearrangement that was identical at the amino acid level 


\begin{tabular}{|c|c|c|c|c|c|c|}
\hline Clone & TCRBV & FW & CDR3 & $\overline{F W}$ & TCRBJ & $\mathrm{n}$ \\
\hline \multicolumn{7}{|c|}{ PBMC } \\
\hline JS1 & BV6S1 & CAS & SLLPANTGEL & FFG & $\mathrm{BJ} 2 \mathrm{~S} 2$ & $1 / 15$ \\
\hline JS2 & BV6S3 & CAS & SPSPTDL & TFG & BJ2S6 & $1 / 15$ \\
\hline JS3 & BV6S5 & CAS & SLGQGSEKL & FFG & BJ1S4 & $1 / 15$ \\
\hline JS4 & BV6S3 & CAS & SLASVSAGEL & FFG & BJ2S2 & $1 / 15$ \\
\hline JS5 & BV6S6 & CAS & SLDATYNEQ & FFG & $\mathrm{BJ} 2 \mathrm{SI}$ & $1 / 15$ \\
\hline JS6 & BV6S1 & CAS & SPTGGVAYEQ & YFG & BJ2S7 & $1 / 15$ \\
\hline JS7 & BV6S2 & CAS & SLEQVDYGY & TFG & BJ1S2 & $1 / 15$ \\
\hline JS8 & BV6S1 & CAS & SLGRGSSYEQ & YFG & BJ2S7 & $1 / 15$ \\
\hline JS9 & BV6S5 & CAS & SLQGGDTEA & FFG & BJ1S1 & $1 / 15$ \\
\hline JS10 & BV6S2 & CAS & STRRAGEL & FFG & $\mathrm{BJ} 2 \mathrm{S2}$ & $1 / 15$ \\
\hline JS11 & BV6S2 & CAS & SEDLGVGQPQ & HFG & BJ1S5 & $1 / 15$ \\
\hline JS12 & BV6S2 & CAS & SLPGGQGTYEQ & YFG & BJ2S7 & $1 / 15$ \\
\hline JS13 & BV6S3 & CAS & SLAGRSSYEQ & YFG & BJ2S7 & $1 / 15$ \\
\hline JS14 & BV6S2 & CAS & LLGQQETQ & YFG & BJ2S5 & $1 / 15$ \\
\hline JS15 & BV6S6 & CAS & SLNEGTEQ & YFG & BJ2S7 & $1 / 15$ \\
\hline \multicolumn{7}{|c|}{$\mathbf{R A}^{+} \mathbf{R O}^{-}$} \\
\hline JS16 & BV6S5 & CAS & SPKWRHYGY & TFG & BJ1S2 & $3 / 23$ \\
\hline JS17 & BV6S2 & CAS & ERDPSWGTDTQ & YFG & BJ2S3 & $2 / 23$ \\
\hline JS18 & BV6S2 & CAG & GVAGEEETQ & YFG & BJ2S5 & $1 / 23$ \\
\hline JS19 & BV6S5 & CAS & SFGWTAPYGY & TFG & $\mathrm{BJ} 1 \mathrm{~S} 2$ & $1 / 23$ \\
\hline JS20 & BV6S3 & CAS & SWDTTLRTDTQ & YFG & BJ2S3 & $1 / 23$ \\
\hline JS21 & BV6S2 & CAS & SIRGASSYNEQ & FFG & $\mathrm{BJ} 2 \mathrm{~S} 1$ & $1 / 23$ \\
\hline JS22 & BV6S3 & CAS & SIGTAYGY & TFG & BJ1S2 & $1 / 23$ \\
\hline JS23 & BV6S2 & CAS & SSGSYEQ & YFG & BJ2S7 & $1 / 23$ \\
\hline JS24 & BV6S1 & CAS & SLTSGRPYEQ & YFG & BJ2S7 & $1 / 23$ \\
\hline JS25 & BV6S3 & CAS & AGLDRVYQETQ & YFG & BJ2S5 & $1 / 23$ \\
\hline JS26 & BV6S2 & CAS & SLATGTSGGWLPSEQ & FFG & BJ2S1 & $1 / 23$ \\
\hline JS27 & BV6S1 & \multicolumn{4}{|c|}{ NONFUNCTIONAL } & $1 / 23$ \\
\hline J\$28 & BV6S2 & CAS & SLFASEGPGGETQ & YFG & BJ2S5 & $1 / 23$ \\
\hline JS29 & BV6S2 & CAS & RSVWGTDTQ & YFG & BJ2S3 & $1 / 23$ \\
\hline JS30 & BV6S6 & CAS & SLNEGTEQ & YFG & BJ2S7 & $1 / 23$ \\
\hline JS31 & BV6S3 & CAS & SLLGHEQ & YFG & BJ2S7 & $1 / 23$ \\
\hline JS32 & BV6S2 & CAS & HAQANGNTI & YFG & BJ1S3 & $1 / 23$ \\
\hline JS33 & BV6S1 & CAS & SLYYNAQGLDTGEL & FFG & BJ2S2 & $1 / 23$ \\
\hline JS34 & BV6S3 & CAS & SKYRGQNSPL & HFG & BJ1S6 & $1 / 23$ \\
\hline JS35 & BV6S3 & CAS & RGGGGHEQ & FFG & BJ2S1 & $1 / 23$ \\
\hline
\end{tabular}

\begin{tabular}{|c|c|c|c|c|c|c|}
\hline Clone & TCRBV & FW & CDR3 & FW & TCRBJ & $n$ \\
\hline \multicolumn{7}{|c|}{ PBMC } \\
\hline LC1 & BV6S5 & CAS & SPGQGETQ & YFG & BJ2S7 & $2 / 17$ \\
\hline $\mathrm{LC} 2$ & BV6S5 & & SRLKATEA & FFG & BJ1S1 & $\begin{array}{l}1 / 17 \\
1 / 1\end{array}$ \\
\hline $\mathrm{LC} 3$ & BV6S1 & NONFT & NCTIONAL & & & $1 / 17$ \\
\hline LC4 & BV6S2 & $\mathrm{CAS}$ & RNRGRRENTEA & FFG & BJ1S1 & $1 / 17$ \\
\hline LC5 & BV6S1 & NONFC & NCTIONAL & & & $1 / 17$ \\
\hline LC6 & BV6S5 & CAS & SLAGTQETQ & YFG & $\mathrm{BJ} 2 \mathrm{~S} 5$ & $1 / 17$ \\
\hline LC7 & BV6S5 & CAS & SADRLWG & NFG & $\mathrm{BJ} 2 \mathrm{~S} 3$ & $1 / 17$ \\
\hline LC8 & BV6S2 & CAS & SFGGPGAL & HFG & BJ1S6 & $1 / 17$ \\
\hline LC9 & BV6S5 & CAS & SLDRGVGY & TFG & BJ1S2 & $1 / 17$ \\
\hline LC10 & BV6S5 & NONFT & NCTIONAL & & & $1 / 17$ \\
\hline LC11 & BV6S5 & CAS & SLAQDYGY & TFG & $\mathrm{BJ} 1 \mathrm{~S} 2$ & $\begin{array}{l}1 / 17 \\
1 / 1\end{array}$ \\
\hline $\mathrm{LC} 12$ & BV6S1 & NONFC & NCTIONAL & & & $1 / 17$ \\
\hline LC13 & BV6S5 & CAS & SGGGKVRYGY & TFG & BJ1S2 & $1 / 17$ \\
\hline LC14 & BV6S5 & CAS & STQVGVGQPQ & $\mathrm{HFG}$ & BJ1S5 & $1 / 17$ \\
\hline LC15 & BV6S2 & CAS & SPGLASTDTQ & YFG & BJ2S 3 & $1 / 17$ \\
\hline LC16 & BV6S2 & CAS & SLREGAEA & FFG & BJ1S1 & $1 / 17$ \\
\hline
\end{tabular}

\section{$\mathbf{R A}^{+} \mathbf{R O}^{-}$}

$\begin{array}{lllllll}\text { LC17 } & \text { BV6S2 } & \text { CAS } & \text { RDPGQDYGY } & \text { TFG } & \text { BJ1S2 } & 3 / 17 \\ \text { LC18 } & \text { BV6S1 } & \text { CAS } & \text { SHGGRRQPQ } & \text { HFG } & \text { BJ1S5 } & 1 / 17 \\ \text { LC19 } & \text { BV655 } & \text { CAS } & \text { RPGTSGETQ } & \text { YFG } & \text { BJ2S5 } & 1 / 17 \\ \text { LC20 } & \text { BV651 } & \text { CAS } & \text { SLGYGEEQ } & \text { YFG } & \text { BJ2S7 } & 1 / 17 \\ \text { LC21 } & \text { BV6S2 } & \text { CAS } & \text { SLELAGYNEQ } & \text { FFG } & \text { BJ2S1 } & 1 / 17 \\ \text { LC22 } & \text { BV6S5 } & \text { CAS } & \text { SLYAGSSYEQ } & \text { YFG } & \text { BJ2S7 } & 1 / 17 \\ \text { LC23 } & \text { BV6S2 } & \text { CAS } & \text { SFGLDTDTQ } & \text { YFG } & \text { BJ2S3 } & 1 / 17 \\ \text { LC24 } & \text { BV6S2 } & \text { CAS } & \text { SLVKGQGPSVVTYEQ } & \text { YFG } & \text { BJ2S7 } & 1 / 17 \\ \text { LC25 } & \text { BV658 } & \text { CAS } & \text { SLALDREPQETQ } & \text { YFG } & \text { BJ2S5 } & 1 / 17 \\ \text { LC26 } & \text { BV6S2 } & \text { CAS } & \text { SLPGIGHRGYEQ } & \text { YFG } & \text { BJ2S7 } & 1 / 17 \\ \text { LC27 } & \text { BV6S5 } & \text { CAS } & \text { SRPSGLAGVREQ } & \text { YFG } & \text { BJ2S7 } & 1 / 17 \\ \text { LC28 } & \text { BV655 } & \text { CAS } & \text { SLGQETQ } & \text { YFG } & \text { BJ2S5 } & 1 / 17 \\ \text { LC29 } & \text { BV652 } & \text { CAS } & \text { SLGRGRGLYNEQ } & \text { FFG } & \text { BJ2S1 } & 1 / 17 \\ \text { LC30 } & \text { BV6S1 } & \text { CAS } & \text { SFGGSYGY } & \text { TFG } & \text { BJ1S2 } & 1 / 17 \\ \text { LC31 } & \text { BV6S5 } & \text { CAS } & \text { SLFPRTSGYEQ } & \text { YFG } & \text { BJ2S7 } & 1 / 17\end{array}$

\section{$\mathbf{R O}^{+} \mathbf{R A}^{-}$}

$\begin{array}{llllllll}\text { LC32 } & \text { BV6S2 } & \text { CAS } & \text { SLGQAYYQ } & \text { YFG } & \text { BJ2S7 } & 8 / 13 & (618) \\ \text { LC33 } & \text { BV6S1 } & \text { CAS } & \text { RDPGQDYGY } & \text { TFG } & \text { BJ1S2 } & 2 / 13 & \\ \text { LC34 } & \text { BV6S1 } & \text { CAS } & \text { SLGYGEEQ } & \text { YFG } & \text { BJ2S7 } & 1 / 13 & \\ \text { LC35 } & \text { BV6S1 } & \text { NONFUNCTIONAL } & & & 1 / 13 & \\ \text { LC36 } & \text { BV6S1 } & \text { CAS } & \text { SLGASGALYNEQ } & \text { FFG } & \text { BJ2S1 } & 1 / 13\end{array}$

\section{PUBLIC FLRGRAYGL CLONOTYPE}

$\begin{array}{llll}\text { BVES2 CAS SLGQAYEQ } & \text { YFG } & \text { BJ2S7 }\end{array}$

\section{$\mathrm{EBV}^{+}$Adult D2}

\begin{tabular}{lllllll}
\hline Clone & TCRBV & FW & \multicolumn{1}{c}{ CDR3 } & FW & TCRBJ & n \\
\hline \multicolumn{2}{l}{ PBMC } & & & & & \\
AS1 & BV6S1 & CAS & SSNRGNEQ & FFG & BJ2S1 & $1 / 12$ \\
AS2 & BV6S2 & CAS & SLLAGEL & FFG & BJ2S2 & $1 / 12$ \\
AS3 & BV6S2 & CAS & SARDGSYEQ & YFG & BJ2S7 & $1 / 12$ \\
AS4 & BV6S3 & NONFUNCIONAL & & & $1 / 12$ \\
AS5 & BV6S3 & CAS & SLGGSGPSSYNEQ & FFG & BJ2S1 & $1 / 12$ \\
AS6 & BV6S6 & CAS & SFSGEETQ & YFG & BJ2S5 & $1 / 12$ \\
AS7 & BV6S1 & NONFUNCTIONAL & & & $1 / 12$ \\
AS8 & BV6S2 & CAS & SLAPGQHSYEQ & YFG & BJ2S7 & $1 / 12$ \\
AS9 & BV6S2 & CAI & GGGGTDTQ & YFG & BJ2S3 & $1 / 12$ \\
AS10 & BV6S1 & CAS & SLNREETQ & YFG & BJ2S5 & $1 / 12$ \\
AS11 & BV6S1 & CAS & SPNRAVGQGVGY & TFG & BJ1S2 & $1 / 12$ \\
AS12 & BV6S1 & CAS & SLVGPDEQ & YFG & BJ2S5 & $1 / 12$
\end{tabular}

\section{$\mathbf{R A}^{+} \mathbf{R O}^{-}$}

$\begin{array}{ll}\text { AS13 } & \text { BV6S1 } \\ \text { AS14 } & \text { BV6S1 } \\ \text { AS15 } & \text { BV6S2 } \\ \text { AS16 } & \text { BV6S1 } \\ \text { AS17 } & \text { BV6S1 } \\ \text { AS18 } & \text { BV6S2 } \\ \text { AS19 } & \text { BV6S5 } \\ \text { AS20 } & \text { BV6S2 } \\ \text { AS21 } & \text { BV6S1 } \\ \text { AS22 } & \text { BV6S2 } \\ \text { AS23 } & \text { BV6S6 } \\ \text { AS24 } & \text { BV6S2 } \\ \text { AS25 } & \text { BV6S2 }\end{array}$

\begin{tabular}{|c|c|c|c|}
\hline \multicolumn{4}{|c|}{ TONAL } \\
\hline CAS & SFSGLAYYNEQ & FFG & BJ2S1 \\
\hline CAS & SSTSGGYTGEL & FFG & BJ2S2 \\
\hline \multicolumn{4}{|c|}{ NONFUNCTIONAL } \\
\hline CAS & SWTGSTDTQ & YFG & $\mathrm{BJ} 2 \mathrm{~S} 3$ \\
\hline CAS & SLAGEETGEL & FFG & BJ2S2 \\
\hline CAS & SSVPSTDTQ & YFG & $\mathrm{BJ} 2 \mathrm{~S} 3$ \\
\hline CAS & SLGQAYEQ & YFG & BJ2S7 \\
\hline \multicolumn{4}{|c|}{ NONFUNCTIIONAL } \\
\hline CAS & SYSASGILVNEQ & FFG & BJ2S1 \\
\hline CAS & SPGQGVGEL & FFG & BJ2S2 \\
\hline CAS & SSPRAGTLGDTQ & YFG & $\mathrm{BJ} 2 \mathrm{~S} 3$ \\
\hline CAS & SFMTSGSSYNEQ & FFG & BJ2S1 \\
\hline
\end{tabular}

$1 / 13$
$1 / 13$
$1 / 13$
$1 / 13$
$1 / 13$
$1 / 13$
$1 / 13$
$1 / 13$
$1 / 13$
$1 / 13$
$1 / 13$
$1 / 13$
$1 / 13$

RO' $^{+}$RA- $^{-}$

AS26 BV6S2 AS27 BV6S2 $\begin{array}{ll}\mathrm{AS} 28 & \text { BV6S1 } \\ \mathrm{AS} 29 & \mathrm{BV} 6 \mathrm{~S} 6\end{array}$

CAS SLGQAYEQ

CAS SPNRAVGQGVNG

$\begin{array}{ll}\text { YFG } & \text { BJ2S7 } \\ \text { TFG } & \text { BJ1S2 } \\ \text { YFG } & \text { BJ2S7 }\end{array}$

\section{PUBLIC FLRGRAYGL CLONOTYPE}

$\begin{array}{llll}\text { BV6S2 CAS SLGQAYEQ } & \text { YFG } & \text { BJ2S7 }\end{array}$

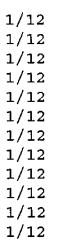

$15 / 18(838)$ $1 / 18$
$1 / 18$

(1)

$1 / 13$
$1 / 13$
$1 / 13$
$1 / 13$
$1 / 13$
$1 / 13$
$1 / 13$
$1 / 13$
$1 / 13$
$1 / 13$
$1 / 13$
$1 / 13$
$1 / 13$



$15 / 18(838)$
$1 / 18 \quad(68)$
$1 / 18$
$1 / 18$

Figure 3. Diversity of TCRBV6 junctional region sequences within different $\mathrm{T}$ cell repertoires of HLA B8 ${ }^{+}$, EBV-seropositive, and EBVseronegative adults. The V-D-J junctional region amino acid sequences of recombinant BV6 clones are shown for unsorted PBMCs and sorted populations of $\mathrm{CD}^{+} \mathrm{CD} 45 \mathrm{RA}^{+} \mathrm{CD} 45 \mathrm{RO}^{-}\left(\mathrm{RA}^{+} \mathrm{RO}^{-}\right)$and $\mathrm{CD} 8^{+}$ $\mathrm{CD}^{4} \mathrm{RO}^{+} \mathrm{CD} 45 \mathrm{RA}^{-}\left(\mathrm{RO}^{+} \mathrm{RA}^{-}\right)$cells of EBV seropositive adults $\mathrm{D} 1$ $(A)$ and $\mathrm{D} 2(B)$ and the seronegative adult D3 $(C)$. The frequency $(n)$ of each clone was determined as detailed in Methods. For comparison, the V-D-J junctional region of the public FLRGRAYGL-specific clonotype is also shown at the bottom of $A$ and $B$. Rearrangements corresponding to the public FLRGRAYGL-specific clonotype are highlighted in bold type. In donor D2 $(B)$ a variant of the public clonotype (clone AS27), involving a single amino acid substitution ( $L$ to $S$ ) in the CDR3 region, was identified that is known to be FLRGRAYGL specific (33). For each clone, the deduced amino acid sequence of the CDR3 loop, defined according to Chothia et al. (43), is shown putatively supported by two frame work branches $(F W)$. Out-of-frame rearrangements are designated nonfunctional. Designations for TCRBJ gene elements follow that of Toyonaga et al. (44) and the TCRBV6 subtypes were assigned according to Arden et al. (22). The nucleotide sequences of each of these clones are available from EMBL/GenBank/ DDBJ under accession numbers AJ224204-AJ224305. 
to the public EBV-specific TCRB chain (Fig. 3, $A$ and $B$ ); the impact of this clonotype was $61 \%$ dominance $(8 / 13$ clones; LC32) in the case of donor D1 and an even higher $83 \%$ dominance (15/18 clones; AS26) in donor D2. This expansion did not result from preferential amplification of either the BV6S2 subfamily or of the SLGQAYEQ CDR3 sequence within the BV6S2 subset since neither of these were found to be overrepresented within the PBMCs and naive populations of either seropositive donor (Fig. 3, $A$ and $B$ ) and of the HLA B8 ${ }^{+}$EBVseronegative donor, D3 (Fig. $3 C$ ). Further confirmation that this TCRB chain's functional identity was the public EBV-specific clonotype was that for each individual, it displayed a unique codon usage within the V-D-J junctional region that corresponded precisely to the TCRB chain sequence of FLRGRAYGL-specific CTLs that previously had been functionally characterized from donors D1 and D2 (data not shown; available from accession numbers AJ224278, AJ224302, and AJ224303) (21) and that it was specific to the two HLA B8 ${ }^{+}$ EBV-infected individuals and was not found in any T cell population within the uninfected HLA B8 ${ }^{+}$donor, D3 (Fig. $3 C$ ). Overall, junctional region sequencing showed that the dominant peaks obtained from CDR3 length analysis were clonal and that they corresponded precisely to the public TCRB chain rearrangement that recognizes the EBV-encoded epitope, FLRGRAYGL. The PBMCs and naive $\mathrm{CD}^{+}$

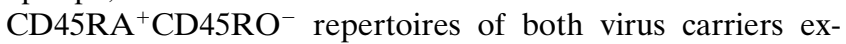
pressed a polyclonal distribution, showing no signs of dramatic clonal predominance (Fig. 3, $A$ and $B$ ). Analysis of data from the seronegative donor, D3, also showed a high degree of clonotype diversity within the PBMCs and $\mathrm{CD}^{+} \mathrm{CD}^{4} 5 \mathrm{RO}^{+}$ $\mathrm{CD}^{2} 4 \mathrm{RA}^{-}$and $\mathrm{CD} 8^{+} \mathrm{CD} 45 \mathrm{RA}^{+} \mathrm{CD}^{-} 5 \mathrm{RO}^{-}{ }^{-}$cell subsets (Fig. $3 C$ ); the only evidence of repertoire perturbation within the memory compartment was a $21 \%$ (4/19 clones) expansion of a functionally undefined TCRBV6S2/BJ2S3 rearrangement (clone JS36). Interestingly, the EBV-specific BV6S2/BJ2S7 rearrangement was detected, albeit at low levels, within the naive compartment of seropositive donor D2 (Fig. $3 \mathrm{~B}$ ).

Repeated repertoire analysis on seropositive donor D2 after 7 mo showed that the EBV-specific clonotype's impressive restriction on TCRBV6 diversity was persistent. Fig. 4 shows an identical $\mathrm{CD}^{+} \mathrm{CD}^{4} 5 \mathrm{RO}^{+} \mathrm{CD} 45 \mathrm{RA}^{-}$repertoire profile to that obtained 7 mo earlier (Fig. $2 A$ ), with $>70 \%$ of clonotypes being dominated by an 8 -amino acid CDR3 length expansion (Fig. $4 A$ ) that was identified by sequencing as the BV6S2/BJ2S7 EBV-specific clonotype (Fig. $4 B$ ).

To fully confirm that the clonal expansions within the memory repertoire represent the public EBV-specific clonotype, the FLRGRAYGL-specific cytotoxicity of the memory and naive $\mathrm{CD}^{+}$populations from seropositive adult $\mathrm{D} 2$ was assessed (Fig. 5). After several weeks of in vitro stimulation, unsorted PBMCs and the $\mathrm{CD}^{+} \mathrm{CD}^{2} 5 \mathrm{RO}^{+} \mathrm{CD} 45 \mathrm{RA}^{-}$subset were found to efficiently lyse target cells sensitized with FLRGRAYGL peptide, whereas the $\mathrm{CD}^{+} \mathrm{CD} 45 \mathrm{RA}^{+} \mathrm{CD} 45 \mathrm{RO}^{-}$ subset showed no detectable cytotoxicity (Fig. 5). These results correlated with the clonotype data that showed a predominance of the EBV-specific BV6S2/BJ2S7 clonotype within the $\mathrm{CD}^{+} \mathrm{CD}^{4} \mathrm{RO}^{+} \mathrm{CD} 45 \mathrm{RA}^{-}$subset. In contrast, low lying pools of virus-specific $\mathrm{T}$ cells such as those that were detected in the naive subset of this donor (Fig. $3 B$ ) are likely to go undetected since they fall below the sensitivity levels of the cytotoxicity assay. Overall, these studies confirmed a functional link for the monoclonally expanded $\mathrm{T}$ cells responsible for major repertoire distortions in healthy HLA $\mathrm{B}^{+}$adults with EBV specificity.

Finally, to measure the full extent of the public EBV-specific clonotype's impact on TCRBV6 repertoire diversity we analyzed the intermediate stained, triple-positive $\mathrm{CD}^{+} \mathrm{CD} 45 \mathrm{RO}^{+}$

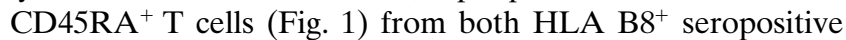
donors for CDR3 length and clonotype distribution (Fig. 6). At present it is unclear whether these $\mathrm{T}$ cells represent a transitional phenotype between the naive and memory subsets, or whether they contain memory cells that have reverted to a naive phenotype (28-30). In seropositive donor, D1, a skewed CDR3 profile was obtained (Fig. $6 A$ ), but these expansions did not correspond in length (Fig. $6 A$ ) nor in rearrangement sequence (Fig. $6 \mathrm{~B}$ ) to the public EBV clonotype. Interestingly, one of these functionally unidentified expansions (clone LC38) was found only within the dual-positive $\mathrm{CD}_{45 \mathrm{RO}^{+}}$ $\mathrm{CD}^{4} \mathrm{RA}^{+}$subset (Fig. $6 \mathrm{~B}$ ) and was not detected in either the naive or memory subsets (Fig. $3 A$ ). The $\mathrm{CD}^{+} \mathrm{CD}^{4} 5 \mathrm{RO}^{+}$ $\mathrm{CD}_{45 \mathrm{RA}^{+}}$repertoire of seropositive donor D2 also displayed evidence of repertoire distortion (Fig. $6 A$ ), but in this donor

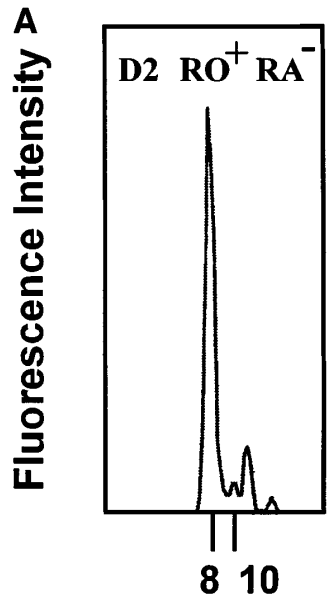

CDR3 Length

\section{EBV $^{+}$ADULT D2}

\begin{tabular}{lcllccc}
\hline Clone & TCRBV & FW & \multicolumn{1}{c}{ CDR3 } & FW & TCRBJ & n \\
\hline RO $^{+}$RA $^{-}$ & & & & & \\
AS30 & BV6S2 & CAS & SLGQAYEQ & YFG & BJ2S7 & $\mathbf{4 / 8}$ \\
AS31 & BV6S2 & CAS & SSGQAYEQ & YFG & BJ2S7 & $\mathbf{1 / 8}$ \\
AS32 & BV6S3 & CAS & SLDPPGQGGEQ & YFG & BJ2S7 & $2 / 8$ \\
AS33 & BV6S3 & CAS & SLGGSASNQPQ & HFG & BJ1S5 & $1 / 8$
\end{tabular}

Figure 4. Repeated analysis of TCRBV6 repertoire diversity

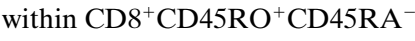
$\left(\mathrm{RO}^{+} \mathrm{RA}^{-}\right)$cells of HLA B8 ${ }^{+}, \mathrm{EBV}-$ seropositive adult $\mathrm{D} 2$ isolated after a 7-mo period. ( $A$ ) CDR3 length profiles are displayed of fluorescence intensity (arbitrary units) as a function of CDR3 size (amino acids) for TCRBV6. (B) The V-D-J junctional region amino acid sequences of recombinant BV6 clones are shown. TCRBV and J gene segments and CDR3 region loops are presented and assigned as outlined in the legend to Fig. 3. The frequency $(n)$ of each clone was determined as detailed in Methods. The nucleotide sequences of each of these clones are available from EMBL/GenBank/DDBJ under accession numbers AJ009914AJ009929. 


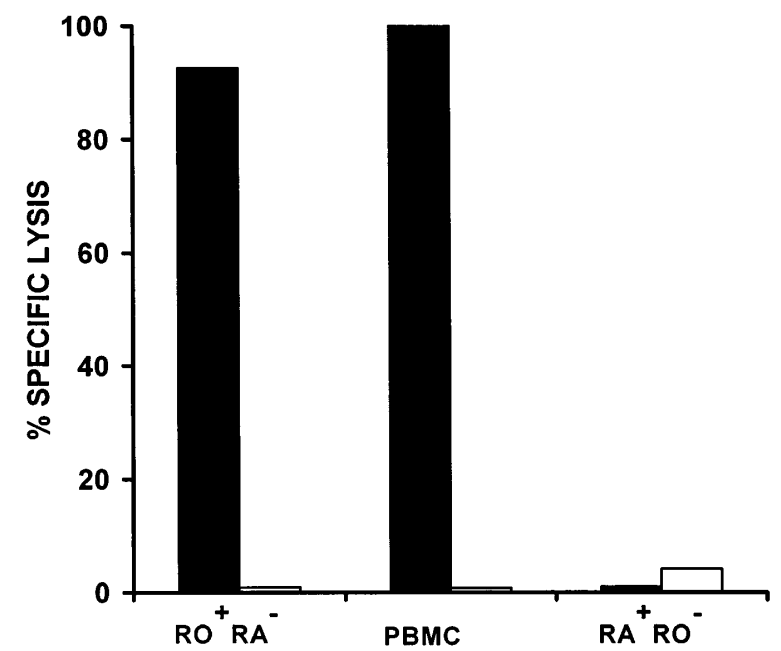

Figure 5. EBV-specific cytotoxicity of different $\mathrm{T}$ cell populations of HLA B8 ${ }^{+}$, EBV-seropositive adult D2. Specific lysis by unsorted PBMCs and sorted $\mathrm{CD}^{+}{ }^{+} \mathrm{CD} 45 \mathrm{RO}^{+} \mathrm{CD} 45 \mathrm{RA}^{-}\left(\mathrm{RO}^{+} \mathrm{RA}^{-}\right)$and $\mathrm{CD}^{+} \mathrm{CD}^{2} 5 \mathrm{RA}^{+} \mathrm{CD} 45 \mathrm{RO}^{-}\left(\mathrm{RA}^{+} \mathrm{RO}^{-}\right)$cells of HLA B8 ${ }^{+}$PHA blasts, with (filled bars) and without (open bars) adsorbed peptide, FLRGRAYGL. Effectors were tested in standard 4-h ${ }^{51} \mathrm{Cr}$-release assays. Effector/target ratio: 10.1 .

one of the expansions proved to be the EBV-specific clonotype (Fig. $6 \mathrm{~B}$ ). Overall, these results show that not only do EBV-specific memory CTLs dominate the $\mathrm{CD}_{4} \mathrm{RO}^{+}$compartment of $\mathrm{CD}^{+} \mathrm{T}$ cells, they can also impact on repertoire diversity within the intermediate $\mathrm{CD} 45 \mathrm{RO}^{+} \mathrm{CD} 45 \mathrm{RA}^{+}$subset of T cells.

\section{Discussion}

This study uses a novel approach in monitoring antigen-specific $\mathrm{T}$ cells within the peripheral blood that provides evidence of a functional link between persistent EBV infection and T cell expansions in healthy adults. A public BV6S2/BJ2S7 clonotype that recognizes the EBV-encoded class I-restricted epitope, FLRGRAYGL, was found to dominate the TCRBV6 repertoire in the $\mathrm{CD} 88^{+} \mathrm{CD} 45 \mathrm{RO}^{+} \mathrm{CD}_{4} \mathrm{RA}^{-}$memory compartment of normal, EBV-seropositive individuals. So dramatic was the impact of selection of this EBV-specific clonotype that it occupied as much as $80 \%$ of the entire TCRBV6 family message. Dominant expansion of a single clonotype within TCRBV6 is significant given that this is one of the most prevalent of the known 25 functional BV families expressed in the normal human repertoire $(31,32)$, containing a higher than average number of seven functional subfamilies (22). Therefore, selection of the EBV-specific clonotype dramatically distorts a large and diverse $\mathrm{BV}$ population. Whether expansion of this clonotype increases the percentage of $\mathrm{CD} 8^{+} \mathrm{T}$ cells expressing BV6 is at present unknown and is difficult to determine given the lack of antibodies specific for the BV6S2 subfamily that is predominantly rearranged to $\mathrm{BJ} 2 \mathrm{~S} 7$ within the public EBV-specific clonotype. However, from a previous study that monitored the relative expression of the BV6 family

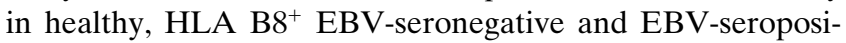
tive adults, no selective increase in TCRBV6 frequency was found to be associated with long-term exposure to EBV (33).

The identification of EBV-specific TCR clonotypes within
A

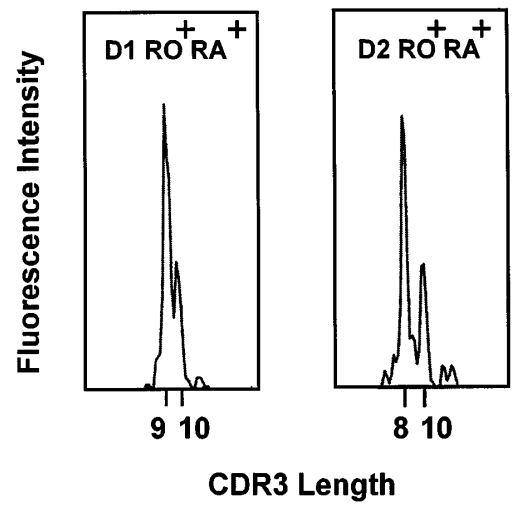

B

\section{EBV $^{+}$ADULT D1}

\begin{tabular}{lllllll}
\hline Clone & TCRBV & FW & CDR3 & FW & TCRBJ & n \\
\hline RO $^{+}$RA & & & & & & \\
LC37 & BV6S1 & CAS & RDPGQDYGY & TFG & BJ1S2 & $12 / 20$ \\
LC38 & BV6S4 & CAS & RYRDDSYNEQ & FFG & BJ2S1 & $6 / 20$ \\
LC39 & BV6S5 & CAS & SLDLAGGLYNE & FFG & BJ2S1 & $1 / 20$ \\
LC40 & BV6S5 & CAS SQWREVNEQ & FFG & BJ2S1 & $1 / 20$
\end{tabular}

EBV $^{+}$ADULT D2

\begin{tabular}{lllllll}
\hline Clone & TCRBV & FW & \multicolumn{1}{c}{ CDR3 } & FW & TCRBJ & n \\
\hline RO' $^{+}$RA $^{+}$ & & & & & \\
AS34 & BV6S2 & CAS SLGQAYEQ & YFG & BJ2S7 & $\mathbf{1 1 / 2 6}$ \\
AS35 & BV6S2 & CAS & SSGQAYEQ & YFG & BJ2S7 & $\mathbf{2 / 2 6}$ \\
AS36 & BV6S1 & CAS SPNRAVGQGVNG & TFG & BJ1S2 & $3 / 26$ \\
AS37 & BV6S1 & NONFUNCTIONAL & & & $3 / 26$ \\
AS38 & BV6S1 & CAS SLILISNTEA & FFG & BJ1S1 & $3 / 26$ \\
AS39 & BV6S3 & CAS SLALATEQ & YFG & BJ2S7 & $1 / 26$ \\
AS40 & BV6S1 & CAS SAWVSSYNEQ & FFG & BJ2S1 & $1 / 26$ \\
AS41 & BV6S3 & CAS SQAPPGGAYEQ & YFG & BJ2S7 & $1 / 26$ \\
AS43 & BV6S3 & CAS SQAPPRGAYEQ & YFG & BJ2S7 & $1 / 26$ \\
& & & & &
\end{tabular}

Figure 6. Diversity of the TCRBV6 repertoire within the intermediate stained $\mathrm{CD} 8{ }^{+} \mathrm{CD} 45 \mathrm{RO}^{+} \mathrm{CD} 45 \mathrm{RA}^{+}\left(\mathrm{RO}^{+} \mathrm{RA}^{+}\right)$repertoires of HLA B8 ${ }^{+}, \mathrm{EBV}$-seropositive donors D1 and D2. ( $A$ ) CDR3 length profiles are displayed of fluorescence intensity (arbitrary units) as a function of CDR3 size (amino acids) for TCRBV6. (B) The V-D-J junctional region amino acid sequences of recombinant BV6 clones are shown. TCRBV and $\mathrm{J}$ gene segments and CDR3 region loops are presented and assigned as outlined in the legend to Fig. 3. The frequency $(n)$ of each clone was determined as detailed in Methods. The nucleotide sequences of each of these clones are available from EMBL/GenBank/DDBJ under accession numbers AJ009914AJ009929.

the $\mathrm{CD} 8^{+} \mathrm{T}$ cell memory subset is consistent with earlier studies that functionally identified EBV-specific CTLs predominantly within the $\mathrm{CD}^{+} \mathrm{CD}^{2} 5 \mathrm{RO}^{+} \mathrm{CD} 45 \mathrm{RA}^{-}$compartment (34). There was also phenotypic heterogeneity between different individuals in detecting the public EBV-specific clonotype within the dual-positive, $\mathrm{CD} 45 \mathrm{RO}^{+} \mathrm{CD}_{45 \mathrm{RA}^{+}}$cells. The significance of this phenotypic heterogeneity is at present unknown, but it may reflect differential levels of antigen-specific $\mathrm{T}$ cell activation in vivo that alter the turnover and/or recycling of antigen-specific cells between the naive and memory pools. Indeed, recent studies by Bunce and Bell (35) suggest that antigen-specific, memory $\mathrm{CD} 4^{+} \mathrm{T}$ cells are divided between two 
different compartments, a CD45RA ${ }^{+}$and a CD45RO ${ }^{+}$subset. In this model antigen restimulation is required for stable maintenance of these memory cells within the $\mathrm{CD}^{2} 5 \mathrm{RO}^{+}$pool. Variable expression of CD45RO and CD45RA may also reflect functional differences among clonotypically identical $\mathrm{T}$ cells such as effector and long-term memory functions. A similar observation has been made recently by Callan et al. (36) using soluble tetrameric MHC for detecting virus-specific T cells in primary EBV-infected donors clinically diagnosed with infectious mononucleosis (IM). In these studies they found that in individuals several years after IM, a subset of virus-specific T cells expressing CD45RA could be detected. This was unlike the situation in IM where the majority of antigen-specific cells expressed CD45RO. Whether, as in our study, these cells coexpress CD45RA and CD45RO was not determined, but this observation could prove to be important in understanding the maintenance and stability of clonotypic expansions within the circulation.

It has been postulated that life-long exposure to repeated or persistent subclinical virus infection may play a key role in the genesis of dramatically expanded $\mathrm{T}$ cell populations within healthy individuals $(8,9,12,37)$. Indeed, several features of $\mathrm{CD}^{+} \mathrm{T}$ cell expansions, including their predominance and persistence within the activated/memory repertoire, are consistent with their development through environmental exposure. We provide evidence in this study that class I-restricted memory CTLs with specificity for EBV contribute to the major expansions that have been documented in the peripheral blood repertoires of healthy individuals. The maintenance of high levels of EBV-specific memory CTLs in healthy individuals throughout life (24) reflects their essential immunosurveillance role in controlling virus infection, a finding that is also characteristic of the long-term persistence of expanded clonotypes in healthy individuals. Indeed, the impressive ability of EBV-specific CTLs to cause complete regression of virusinduced lymphoproliferative lesions in immunosuppressed patients $(38,39)$ strongly suggests that their prevalence and dramatic impact on repertoire diversity are important for maintaining the life-long asymptomatic virus-host balance in normal health. Overall, EBV immunity is likely to have a major impact on repertoire diversity within a large proportion of the human population given the ubiquitous nature of this herpesvirus infection and the unprecedented level of TCR restriction that appears to be associated with the long-term memory CTL response to EBV. Aside from the HLA B8-restricted FLRGRAYGL response, we have identified recently several other highly restricted EBV-specific TCR responses that are presented through a range of HLA alleles. Studies are underway to assess the impact on repertoire diversity of these CD8 ${ }^{+}$ $\mathrm{T}$ cell memory responses.

Using the elegant MHC class I-peptide tetramer technol-

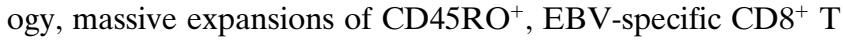
cells have been documented recently within individuals afflicted by IM (36). Resolution of the disease and transition to the long-term virus carrier state are accompanied by a fall in virus-specific $\mathrm{T}$ cell precursors; the tetrameric complexes estimated the frequency of EBV-specific $\mathrm{T}$ cells of a defined epitope specificity as $<0.5 \% \mathrm{CD}^{+} \mathrm{T}$ cells in healthy virus carriers. Despite the culling of large numbers of virus-specific $\mathrm{T}$ cells after the peak of lymphoproliferation in IM, it is clear from the findings in this study that the resulting frequencies in healthy donors long term after primary infection can signifi- cantly alter the $\alpha \beta$ memory repertoire. This most likely is linked with the unusually high degree of TCR restriction that exists within the T cell response for the EBV-encoded epitope, FLRGRAYGL (21). Given the limitation of tetramer technology in only detecting antigen-specific $\mathrm{T}$ cells at $>0.1 \%$ to $0.5 \%$ of $\mathrm{CD}^{+} \mathrm{T}$ cells (40), our approach at present provides a reliable and sensitive method of tracking virus-specific $\mathrm{CD}^{+}$ $\mathrm{T}$ cells in long-term memory responses.

The identified origin of these stably expanded clonotypes and their role in maintaining a balanced host-virus relationship in normal health is extremely important to studies interpreting patterns of clonal dominance in disease. Indeed, distinct patterns of clonal restriction and structural evidence of antigen specificity within the TCR V, J, and CDR3 regions have often been interpreted as evidence for a role of these $T$ cells in disease pathogenesis. However, our findings emphasize the importance of HLA restriction and EBV immunostatus on the outcome of studies comparing peripheral blood repertoire diversity in health and disease. We would also predict that other highly focused, immunodominant memory $\mathrm{T}$ cell responses are likely to dramatically skew TCR repertoire distribution in healthy individuals. For example, dominant public TCR responses have also been reported in influenza virus infection (41). Ultimately, knowledge of $\mathrm{T}$ cell specificity is needed to address the issue of an immunoregulatory role versus stimulation by unrelated factors of expanded $\mathrm{T}$ cells in disease. Interestingly, this study also shows that the $\mathrm{CD}^{+} \mathrm{T}$ cells

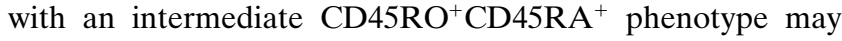
also harbor major clonotype expansions that are precluded from standard analyses that define strongly positive CD45RA ${ }^{+}$ and $\mathrm{CD} 45 \mathrm{RO}^{+}$phenotypes as naive and memory cells, respectively. More recent studies that have used CD45RA and CD27 expression to separate naive, memory, and effector human $\mathrm{CD}^{+} \mathrm{T}$ cells within the circulation (42) might also prove useful in monitoring expansion development and in unraveling their functional significance. Overall, this first identified link for $\mathrm{CD}^{+} \mathrm{T}$ cell expansions provides the basis for future studies monitoring the development of extreme clonal dominance within the normal repertoire and the effects of aging and disease on repertoire progression.

\section{Acknowledgments}

We thank Dr. Xiaohua Chen and Alana Goldman for their helpful assistance in using the Applied Biosystems 373A DNA sequencer and the GENESCAN Analysis 2.1 Software, Grace Chojnowski and Paula Hall for their expert technical assistance with FACS ${ }^{\circledR}$ sorting, Drs. Scott Burrows and Rajiv Khanna for critically reviewing the manuscript, and Dr. John Whitson for performing the blood collections.

This work was supported by the National Health and Medical Research Council of Australia.

\section{References}

1. Kluin-Nelemans, J.C., M.G.D. Kester, J.J. Melenhorst, J.E. Landegent, L. van de Corput, R. Willemze, and J.H.F. Falkenburg. 1996. Persistent clonal excess and skewed $\mathrm{T}$ cell repertoire in $\mathrm{T}$ cells from patients with hairy cell leukemia. Blood. 87:3795-3802

2. Moss, P., G. Gillespie, P. Frodsham, J. Bell, and H. Reyburn. 1996. Clonal populations of $\mathrm{CD}^{+}$and $\mathrm{CD}^{+} \mathrm{T}$ cells in patients with multiple myeloma and paraproteinemia. Blood. 87:3297-3306.

3. Choi, Y., J.A. Lafferty, J.R. Clements, J.K. Todd, E.W. Gelfand, J. Kappler, P. Marrack, and B.L. Kotzin. 1990. Selective expansion of T cells expressing V $\beta 2$ in toxic shock syndrome. J. Exp. Med. 172:981-984. 
4. Paliard, X., S.G. West, J.A. Lafferty, J.R. Clements, J.W. Kappler, and P. Marrack. 1991. Evidence for the effects of a superantigen in rheumatoid arthritis. Science. 253:325-329.

5. Wucherpfennig, K.W., and D.A. Hafler. 1995. A review of T cell receptors in multiple sclerosis: clonal expansion and persistence of human $\mathrm{T}$ cells specific for an immunodominant myelin basic protein peptide. Ann. NY Acad. Sci. 756:241-258

6. Pantaleo, G., J.F. Demarest, H. Soudeyns, C. Graziosi, F. Denis, J.W. Adelsberger, P. Borrow, M.S. Saag, G.M. Shaw, R.P. Sekaly, and A.S. Fauci. 1994. Major expansion of $\mathrm{CD} 8^{+} \mathrm{T}$ cells with a predominant $\mathrm{v}$ beta usage during the primary immune response to HIV. Nature. 370:463-467.

7. Callan, M.F.C., N. Steven, P. Krausa, J.D.K. Wilson, P.A.H. Moss, G.M. Gillespie, J.I. Bell, A.B. Rickinson, and A.J. McMichael. 1996. Large clonal expansions of $\mathrm{CD}^{+} \mathrm{T}$ cells in acute infectious mononucleosis. Nat. Med. 2:906911.

8. Posnett, D.N., R. Sinha, S. Kabak, and C. Russo. 1994. Clonal populations of $\mathrm{T}$ cells in normal elderly humans: the $\mathrm{T}$ cell equivalent to "benign monoclonal gammopathy." J. Exp. Med. 179:609-618.

9. Schwab, R., P. Szabo, J.S. Manavalan, M.E. Weksler, D.N. Posnett, C. Pannetier, P. Kourilsky, and J. Even. 1997. Expanded CD4 ${ }^{+}$and $\mathrm{CD}^{+}$T cell clones in elderly humans. J. Immunol. 158:4493-4499.

10. Wang, E.C.Y., P.A.H. Moss, P. Frodsham, P.J. Lehner, J.I. Bell, and L.K. Borysiewicz. 1995. CD8 high CD57 ${ }^{+}$T lymphocytes in normal, healthy individuals are oligoclonal and respond to human cytomegalovirus. J. Immunol. 155:5046-5056.

11. Bonfert, V., J. Cihak, U. Losch, and H.W.L. Ziegler-Heitbrock. 1995. Preferential expression of $\mathrm{V}$ beta gene families in CD8 memory cells of apparently healthy donors. Cell. Immunol. 166:165-171.

12. Hingorani, R., I.H. Choi, P. Akolkar, B. Gulwani Akolkar, R. Pergolizzi, J. Silver, and P.K. Gregersen. 1993. Clonal predominance of T cell receptors within the $\mathrm{CD}^{+} \mathrm{CD}^{4} 5 \mathrm{RO}^{+}$subset in normal human subjects. J. Immunol. 151:5762-5769.

13. Grunewald, J., M. Jeddi-Tehrani, H. DerSimonian, R. Andersson, and H. Wigzell. 1992. A persistent T cell expansion in the peripheral blood of a normal adult male: a new clinical entity? Clin. Exp. Immunol. 89:279-284.

14. Fitzgerald, J.E., N.S. Ricalton, A. Meyer, S.G. West, H. Kaplan, C. Behrendt, and B.L. Kotzin. 1995. Analysis of clonal CD8 ${ }^{+}$T cell expansions in normal individuals and patients with rheumatoid arthritis. J. Immunol. 154: 3538-3547.

15. Morley, J.K., F.M. Batliwalla, R. Hingorani, and P.K. Gregersen. 1995 Oligoclonal $\mathrm{CD} 8^{+} \mathrm{T}$ cells are preferentially expanded in the $\mathrm{CD} 57^{+}$subset. $J$. Immunol. 154:6182-6190.

16. Lantelme, E., L. Granziero, L. Angman, and C. Giachino. 1997. Clonal predominance, but preservation of a polyclonal reservoir, in normal alpha beta T cell repertoire. Hum. Immunol. 53:49-56.

17. Hedrick, S.M., and F.J. Eidelman. 1993. T lymphocyte antigen receptor. In Fundamental Immunology. W.E. Paul, editor. Raven Press, New York. 383420 .

18. Jorgensen, J.L., U. Esser, B. Fazekas de St. Groth, P.A. Reay, and M.M. Davis. 1992. Mapping TCR-peptide contacts by variant peptide immunization of single-chain transgenics. Nature. 355:224-230.

19. Garcia, K.C., M. Degano, R.L. Stanfield, A. Brunmark, M.R. Jackson, P.A. Peterson, L. Teyton, and I.A. Wilson. 1996. An alpha-beta T cell receptor structure at 2.5 angstrom and its orientation in the TCR-MHC complex. Science. 274:209-219.

20. Garboczi, D.N., P. Ghosh, U. Utz, Q.R. Fan, W.E. Biddison, and D.C. Wiley. 1996. Structure of the complex between human T cell receptor, viral peptide and HLA-A2. Nature. 384:134-141.

21. Argaet, V.P., C.W. Schmidt, S.R. Burrows, S.L. Silins, M.G. Kurilla, D.L. Doolan, A. Suhrbier, D.J. Moss, E. Kieff, T.B. Sculley, and I.S. Misko. 1994. Dominant selection of an invariant $\mathrm{T}$ cell antigen receptor in response to persistent infection by Epstein-Barr virus. J. Exp. Med. 180:2335-2340.

22. Arden, B., S.P. Clark, D. Kabelitz, and T.W. Mak. 1995. Human T cell receptor variable gene segment families. Immunogenetics. 42:455-500.

23. Silins, S.L., S.R. Burrows, D.J. Moss, R. Khanna, I.S. Misko, and V.P. Argaet. 1995. T cell receptor repertoire for a viral epitope in humans is diversified by tolerance to a background major histocompatibility complex antigen. $J$. Exp. Med. 182:1-13.

24. Bourgault, I., A. Gomez, E. Gomard, and J.P. Levy. 1991. Limiting-dilution analysis of the HLA restriction of anti-Epstein-Barr virus-specific cyto- toxic T lymphocytes. Clin. Exp. Immunol. 84:501.

25. Panzara, M.A., E. Gussoni, L. Steinman, and J.R. Oksenberg. 1992 Analysis of the $\mathrm{T}$ cell repertoire using the PCR and specific oligonucleotide primers. Biotechniques. 12:728-735.

26. Pannetier, C., M. Cochet, S. Darche, A. Casrouge, M. Zöller, and P. Kourilsky. 1993. The sizes of the CDR3 hypervariable regions of the murine T cell receptor beta chains vary as a function of the recombined germ-line. Proc. Natl. Acad. Sci. USA. 90:4319-4323.

27. Pannetier, C., J. Even, and P. Kourilsky. 1995. T cell repertoire diversity and clonal expansions in normal and clinical samples. Immunol. Today. 16:176181.

28. Bell, E.B., and S.M. Sparshott. 1990. Interconversion of CD45R subsets of CD4 T cells in vivo. Nature. 348:163-166.

29. Rocha, B., C. Penit, C. Baron, F. Vasseur, N. Dautigny, and A.A. Freitas. 1990. Accumulation of bromodeoxyuridine-labeled cells in central and peripheral organs: minimal estimates of production and turnover rates of mature lymphocytes. Eur. J. Immunol. 20:1697.

30. Sprent, J., and D.F. Tough. 1994. Lymphocyte life-span and memory. Science. 265:1395-1400.

31. Rosenberg, W.M., P.A. Moss, and J.I. Bell. 1992. Variation in human T cell receptor $\mathrm{V}$ beta and $\mathrm{J}$ beta repertoire: analysis using anchor polymerase chain reaction. Eur. J. Immunol. 22:541-549.

32. Loveridge, J.A., W.M. Rosenberg, T.B. Kirkwood, and J.I. Bell. 1991 The genetic contribution to human T cell receptor repertoire. Immunology. 74 246-250.

33. Silins, S.L., S.M. Cross, S.L. Elliott, S.J. Pye, S.R. Burrows, J.M. Burrows, D.J. Moss, V.P. Argaet, and I.S. Misko. 1996. Development of EpsteinBarr virus-specific memory $\mathrm{T}$ cell receptor clonotypes in acute infectious mononucleosis. J. Exp. Med. 184:1815-1824.

34. Merkenschlager, M., and P.C.L. Beverley. 1989. Evidence for differential expression of CD45 isoforms by precursors for memory-dependent and independent cytotoxic responses: human CD8 memory CTLp selectively express CD45RO (UCHL1). Int. Immunol. 1:450-459.

35. Bunce, C., and E.B. Bell. 1997. CD45RC isoforms define two types of CD4 memory T cells, one of which depends on persisting antigen. J. Exp. Med. 185:767-776.

36. Callan, M.F.C., L. Tan, N. Annels, G.S. Ogg, J.D.K. Wilson, C.A O'Callaghan, N. Steven, A.J. McMichael, and A.B. Rickinson. 1998. Direct visualization of antigen-specific $\mathrm{CD}^{+} \mathrm{T}$ cells during the primary immune response to Epstein-Barr virus in vivo. J. Exp. Med. 187:1395-1402.

37. Grunewald, J., and H. Wigzell. 1996. T cell expansions in healthy individuals. The Immunologist. 4:99-103.

38. Papadopoulos, E.B., M. Ladanyi, D. Emanuel, S. Mackinnon, F. Boulad, M.H. Carabasi, H. Castro-Melaspina, B.H. Childs, A.P. Gillio, T.N. Small, et al. 1994. Infusions of donor leukocytes to treat Epstein-Barr virus-associated lymphoproliferative disorders after allogeneic bone marrow transplantation. $N$. Engl. J. Med. 330:1185-1191.

39. Rooney, C.M., C.A. Smith, C.Y.C. Ng, S. Loftin, C. Li, R.A. Krance, M.K. Brenner, and H.E. Heslop. 1995. Use of gene-modified virus-specific T lymphocytes to control Epstein-Barr virus-related lymphoproliferation. Lancet. 345:9-13.

40. Kuroda, M.J., J.E. Schmitz, D.H. Barouch, A. Craiu, T.M. Allen, A. Sette, D.I. Watkins, M.A. Forman, and N.L. Letvin. 1998. Analysis of Gag-specific cytotoxic T lymphocytes in simian immunodeficiency virus-infected rhesus monkeys by cell complex class I-peptide complex. J. Exp. Med. 187:1373-1381.

41. Lehner, P.J., E.C.Y. Wang, P.A.H. Moss, S. Williams, K. Platt, S.M Friedman, J.I. Bell, and L.K. Borysiewicz. 1995. Human HLA-A0201-restricted cytotoxic T lymphocyte recognition of influenza $\mathrm{A}$ is dominated by $\mathrm{T}$ cells bearing the Vß17 gene segment. J. Exp. Med. 181:79-91.

42. Hamann, D., P.A. Baars, M.H.G. Rep, B. Hooibrink, S.R. KerkhofGarde, M.R. Klein, and R.A.W. van Lier. 1997. Phenotypic and functional separation of memory and effector human $\mathrm{CD}^{+}$T cells. J. Exp. Med. 186:14071418

43. Chothia, C., D.R. Boswell, and A.M. Lesk. 1988. The outline structure of the T cell alpha beta receptor. EMBO (Eur. Mol. Biol. Organ.) J. 7:37453755

44. Toyonaga, B., Y. Yoshikai, V. Vadasz, B. Chin, and T.W. Mak. 1985. Organization and sequences of the diversity, joining, and constant region genes of the human T cell receptor beta chain. Proc. Natl. Acad. Sci. USA. 82:86248628 . 